\title{
Developing the enterprise educators' mindset to change the teaching methodology: the case of Creating Entrepreneurial Outcomes (CEO) Programme
}

\author{
Jing Zhang ${ }^{1} \cdot$ Alison Price ${ }^{2}$
}

Received: 6 September 2020 / Revised: 10 September 2020 / Accepted: 18 September 2020 /

Published online: 30 September 2020

(c) Springer Nature Singapore Pte Ltd. 2020

\begin{abstract}
The 'Creating Entrepreneurial Outcomes' (CEO) Programme is the very first UKChina co-created educator training programme designed to address China's enterprise education needs by drawing upon the recent traditions of European and UK enterprise education practice. The paper outlines the range of foundational educational and entrepreneurial concepts that have influenced the design of the CEO programme. The objective of the CEO programme is to develop the educators' mindset and teaching methodology, which for many in China is a significant paradigm shift from traditional content-centred teaching to student-centred learning. It seeks to combine good practice from a wide range of subject disciplines to support the needs of enterprise educators as they seek to deliver on the complex challenge of transferring knowledge, building skills and developing learner confidence in their practice. This co-created approach resulted in the development of the 'CEO Canvas' as the user-focused approach underpinning approach for the enterprise education curriculum design which has proved valid with over 3000 educators, despite the differences in the policy focus and profiles of the delegates.
\end{abstract}

Keywords Entrepreneurship and enterprise education - Pedagogical alignment · Creating Entrepreneurial Outcomes $\cdot$ Staff development $\cdot$ Higher education $\cdot$ China

Alison Price

alison@enterpriseevolution.org.uk

Jing Zhang

bczhangjing@163.com

1 Beijing Vision Chang International Education and Culture Consultancy Company Ltd, Beijing, China

2 Enterprise Evolution UK, Liverpool, UK 


\section{Introduction}

The General Office of the Chinese Ministry of Education (2012) called upon all degree-awarding institutions to deliver entrepreneurship education across the entire Chinese higher education sector, an act which immediately created a need for staff development. Such instantaneous demand to upskill academic staff led to a rapidly expanding market response, with many imported approaches from outside China being sought (Zhang 2018) in the hope of ensuring all institutions could deliver on this mandated requirement for two-credit bearing (32-h) teaching.

This paper presents a case study of one such response: the CEO programme (Creating Entrepreneurial Outcomes Programme) which was jointly developed by sector expertise from both China and UK, making it the only co-created staff development programme for enterprise education. This paper briefly outlines the range of underpinning educational and entrepreneurial concepts, as well as the operational constraints, that have influenced the design of the CEO programme as a more rounded response to China's urgent educational needs. Rather than installing a predetermined approach, the CEO programme seeks to contextualise the emerging best practice that typifies the UK enterprise education within the specific situation of the traditional Chinese higher education system. This case study aims to show how full pedagogical alignment throughout the programme design and delivery can work to change the educator's mindset and ultimately their pedagogical approach. This research is evidenced through delegate evaluation (satisfaction and recommendation rates) and written participant testimony and is presented here as the basis for further study: an impact assessment of CEO educators.

\section{Background}

China's enterprise education needs have been emerging in recent years, following the global pattern that has seen international observers, policy makers and economists increasingly recognise the critical role of innovation, start-ups and entrepreneurial graduates in creating growth in a national economy (Fayolle and Gailly 2008). National recognition of the potential that business start-ups offer is evident across Mainland China as indicators from the Global Entrepreneurship Monitor (GEM 2020) suggest that $74.9 \%$ adults appreciate that there are good opportunities to start a business in their own area. With $67.4 \%$ believing that they have the appropriate skills and knowledge (Bosma et al. 2020: 98), the Global Entrepreneurship Monitor (2020) also reports that whilst $39.7 \%$ intend to make a difference, $44.7 \%$ indicate fear of failure and only $21.4 \%$ have entrepreneurial intentions. As mainland China ranks 47 out of 50 in the level of intrapreneurship $(0.2 \%)$, there is certainly a role for enterprise education to play to the nation's self-efficacy (Bandura 1977) and motivation for entrepreneurship.

Within this increasing global focus on the potential of Higher Education (HE) to create graduate start-ups (APPG 2018), the need to establish a start-up 
pipeline within higher education has been recognised in China. In August 2012, the Ministry of Education issued its basic national requirements for entrepreneurship teaching for undergraduate students. It was decreed that over the course of all undergraduate study, students must attend at least $32 \mathrm{~h}$ of classes covering a set of pre-determined knowledge-focused topics. This included entrepreneurship and career development, entrepreneurial traits and entrepreneur teams, entrepreneurship opportunities and risks, resources, business plans and new venture creation. The vast majority of universities responded by setting up a stand-alone course over one semester which was taught by different functional departments or schools, such as a business school, recruitment and employment office, youth league, student affairs office or a newly established enterprise school. Most of this teaching would be recognised within the original tradition of teaching 'about' entrepreneurship (QAA 2018). This follows a didactic approach to teaching that provides limited exposure to entrepreneurial practice. Such an approach seeks to deliver through an educational model of knowledge acquisition, rather than what the UK Quality Assurance Agency Guidance for UK Higher Education Providers on Enterprise and Entrepreneurship Education (QAA 2018) recognises, as the more impactful, 'for' entrepreneurship (p. 13). Drawing upon this QAA classification, which stems from the pivotal work of Levie (1999), "learning 'for' entrepreneurship (QAA 2018:13) and has, over the last 20 years, become the prevalent model within the UK. This focuses on personal and skill or competence development, creating a model with a more 'practical goal' than was traditionally seen in higher education in China. Whilst the development of enterprise education is still recognised to be at an early stage (Liu et al. 2020), the opportunity to take this more student-centred approach has yet to be seized within staff development.

In determining the provision of innovation and entrepreneurship education in universities and vocational colleges as compulsory, the Chinese government was able to draw upon a highly effective, top-down approach. This used various channels and drivers to create change such as policy papers, selection of model universities/colleges and entrepreneurship competitions to deliver the message nationally.

It is interesting to compare this to the UK government's own approach in the late 1990s which sought to build upon Dearing's (1997) call to create a third mission (in addition to the two core missions of research and teaching) and encourage UK universities to attempt to replicate the US university spin-out and start-up rates (Science Enterprise Challenge Department for Trade and Industry (DTI) 2000, 2003). But without the governmental powers to direct UK institutions, longer lead times are needed to create sector-wide and institutional change, whereas, in a country like China where government plays a steering role, government initiatives are implemented by all education providers without compromise. However, from the authors' own sector analysis, such directive policy has seen the emergence of four critical responses within Chinese higher education. Firstly, whilst many academics recognise that entrepreneurship education is not just about new venture creation, they are mandated to teach start-up related topics and arrange for students to attend competitions based on business plans and pitches. This creates a narrow articulation of enterprise ( $\mathrm{Li}$ et al. 2003) which potentially limits its longer term impact when compared with the UK acceptance of students as lifelong learners, building 
both enterprise and employability skills (Knight and Yorke 2004) throughout their university experience and beyond. Secondly, as few academics have a business background, their teaching is focused upon a particular textbook and case studies, creating an approach to teaching that has limited potential to build skills and confidence in their students. Thirdly, there is no credit or recognition 'outside the classroom' because the teaching model in China recognises only classroom contact hours. Students are not expected to practice what they are taught after or outside the classroom. This significantly limits staff motivation for engaging with the newer modes of delivery (Lackeus 2015) that now typify delivery of UK enterprise education such as experiential (Pepin 2012), problem-based (San Tan and Ng 2006), real-world (Robinson et al. 2008) and authentic learning (Bliemel 2016). Finally, where universities and vocational colleges seek external support it has been observed within this sector analysis that many institutions draw in commercial training companies. Their focus tends to help students fine tune their presentations and business plans in order to excel in business start-up or pitching competitions.

\section{Pedagogical underpinning}

Collectively, these factors are creating sector-wide limitations on the understanding and application of enterprise education. They work collectively to create an approach to enterprise education which can be classified as being taught primarily within traditional didactic modes, or 'about' entrepreneurship as defined within the QAA Guidance on Enterprise and Entrepreneurship Education (2012) with impact measures and determinants of successful teaching being demonstrated through achievement in competitions. Ultimately, it can be seen that national expediency has created a sector-wide response which efficiently addresses the policy demands of 2012 through an annual cycle of venture creation. However, given that the more varied 'entrepreneurship education, using active learning methods, can be at odds with traditional Chinese educational practices' (Bell 2020:1) the need for culturally rooted and pedagogically aligned staff development is clear.

In May 2015, the General Office of the State Council issued a key document presented as 'Opinions on Deepening the Reform of Innovation and Entrepreneurship Education in Colleges and Universities' known as 'No. 36 Policy' amongst educators. This key document, whilst not mandatory, offered a more strategic picture of how innovation and entrepreneurship education should be provided. It referenced systemic reform of the innovation and entrepreneurship education curriculum and suggested that enterprise should be embedded into the curriculum and required reform of teaching and assessment methods. This pivotal document sought to engage more subject-specific educators to the challenge of teaching enterprise by identifying specific expectations relating to 'how to' teach, rather than just 'what' to teach (echoing the UK Lord Young Review 2014).

The challenge presented in 'No. 36 Policy' (General Office of the State Council 2015) was to encourage staff in delivering enterprise education as 'for' (QAA 2018) enterprise. This compared directly with the emerging UK paradigm of enterprise education staff development which had been driven by the pioneering 
work of the late Professor Gibb (1993, 2002, 2005a, b, 2007a, b; Gibb and Price 2014). His approach focused on building an entrepreneur's mindset and behaviours within subject specialisms rather than offering a 'bolt-on' of entrepreneurial knowledge acquisition into the university experience and thereby established the idea of embedding enterprise into the curriculum.

Thus, UK enterprise education staff development abandoned the traditional business school model of knowledge-based inputs in favour of the active exploration of:

- Entrepreneurial behaviours, skills and attributes (competences)

- Entrepreneurial values and ways of doing things, feeling things, organising things, communicating things and learning things experientially

- Having and harvesting ideas (know how)

- Managing and learning from relationships (know who)

(Gibb and Price 2014)

This has sought to use of pedagogical techniques that favoured 'learning by doing' in order to stimulate entrepreneurship (Neck and Corbett 2018). Anchored by personal, peer-to-peer and facilitated/cohort-level reflection, these techniques moved the educator away from models of mass instruction (Elton 1977) and knowledge transfer. This recognised the need for students to solve problems and respond with creativity and insight by applying knowledge and demonstrating competence and confidence in its use. This heralded the abandonment of a heavy reliance on the traditional role of the educator as primarily transmitting knowledge through mass instruction, acting only as the 'sage on the stage'. This shift can be summarised by Gibb's (2007a, b) table (Table 1) on the focus of learning presented below.

Such a change in mindset ultimately creates a new role for the academic as an active agent within student learning, supporting personal development through experiential and action-oriented learning in the UK. This permanently defined the enterprise education professional as taking the role of 'guide on the side'-a supportive facilitator of learning. This specific focus upon the role of enterprise

Table 1 The focus of learning (Gibb 2007a, b)

\begin{tabular}{ll}
\hline From & To \\
The past & The future \\
\hline Critical analysis & Creativity \\
Knowledge & Insight \\
Passive understanding & Active understanding \\
Absolute detachment & Emotional involvement \\
Manipulation of symbols & Manipulation of events \\
Written communication and neutrality & Personal communication and influence \\
Concept/theory & Conceptualising a problem or opportunity \\
\hline
\end{tabular}

Gibb (2007a, b) 
educator has galvanised in the UK as both academic (Hannon 2018; Langston 2018) and policy review (Lord Young Review 2014) have placed the educator's mindset and experience as critical to effective delivery.

The fast-paced changing demands within the national Chinese educational policy are emerging into a recognised, but unmet, need to align the role of the educator as well as create new pedagogical traditions to underpin a new approach within China to develop the enterprise educator's mindset. The development of the CEO programme therefore draws upon the UK educational (enterprise staff development) traditions and explores what could form transferable best practice as a response to specific needs of Chinese educators. The CEO programme recognises that for many academic staff in China, adopting a new teaching methodology would require a significant mindset shift from traditional content-centred teaching to student-centred learning.

\section{Understanding the Context: Informing the design of the CEO programme}

The CEO programme is an international learning and teaching programme for educators which seeks, as the name suggests, to 'create entrepreneurial outcomes' in others. It recognises the role that educators can play in supporting the development of entrepreneurial graduates and explores how an aligned curriculum can build skills and knowledge in our learners through the selection of appropriate teaching techniques that support the development of entrepreneurial skills and competences. The CEO programme has been shaped by a China-wide sector analysis drawn from sector observations and direct staff insights and commentary which highlighted a number of distinct issues within higher education. These ranged from staff resistance, curriculum issues such as poor alignment to intended outcomes, didactic teaching and limited space in the curriculum as well as recognising the environmental constraints of the institutional teaching environment. These issues are discussed below.

Firstly, the vast majority of those who are involved in entrepreneurship education regard the teaching as a new or additional role requirement ('a task they had to undertake'). This can create a negative mindset in educators from which the CEO programme is specifically designed to highlight the rationale behind the government policy which recognise the national opportunities provided by graduates that are entrepreneurial (Herrmann et al. 2008). By utilising the good practice within UK staff development (Gibb 2011), the student is placed at the heart of the programme design, creating a mindset shift whereby delegates are committed to enhancing their students' learning experience.

Secondly, the CEO programme challenges delegates' prevailing ideas that entrepreneurship education is just about creating new ventures. Despite the recommendations to alter the national position (such as 'Policy No. 36' General Office of the State Council 2015), our findings indicate that the majority of higher education institutions are still teaching the topics set by the Ministry of Education in their requirement issued in 2012. Entrepreneurship competitions remain a key assessment vehicle in which traditional business plans and elevator pitches are presented to judging panels that are made up of investors rather than educators. High profile success in 
such competitions has a huge impact on both individuals and institutions as a whole and remains popular due to the hard metrics they provide.

Thirdly, all Chinese undergraduates are required to attend 'public compulsory courses' such as English and Politics. Although these are not related to their degree (Major), they still form a recognised requirement within an undergraduate degree. With the addition of $32 \mathrm{~h}$ on a mandated entrepreneurship course, it remains a challenge to equip students with entrepreneurial mindset and competences. Clearly, the UK model of embedding the enterprise into the curriculum (Kill and O'Rourke 2011) is critical in resolving this.

Fourthly, entrepreneurship education outcomes are typically targeted upon the ability to apply learning and enhancing capability to take action rather than focusing purely upon the conventional delivery with testing and critical assessment of knowledge inputs (Gibb 2011). This requires a significant shift to delivery as the majority of Chinese classes are dominated by the traditional delivery mode of a lecture informed by a specific textbook. The CEO programme works with a student-centred approach that provides staff with the tools and process ('CEO Canvas') to design their own approach.

Finally, Chinese class sizes are usually large in number with desks and chairs fixed to the floor, which makes interaction physically difficult and socially inhibiting. Within a more passive learning environment, teaching staff report having to compete with mobile phones for students' attention, with students' lack of motivation and engagement cited as the biggest challenge. Anecdotally, educators often report facing a paradox: when lecturing to their large student groups, they do not feel that their students pay attention, yet fear that engaging students more actively would require extended class time and a teaching environment that is not possible within current timetable constraints. Within such pressure to deliver, the CEO programme seeks to recognise this paradox. It is designed to provide participants with opportunities to experience approximately 50 teaching techniques throughout the programme whilst allowing sufficient time for reflection and adaptation. This ensures that delegates can 'take away' effective techniques and adapt them to their own teaching.

The CEO programme is a specifically designed and uniquely co-created response to help Chinese educators address national needs and the challenge of implementing the needs of the national government. Through an extended period of sector examination, bilateral disclosure and exchange which was guided by institutional feedback and insight, a working model has been developed that is able to meet diverse group needs whilst remaining grounded by key delivery and design principles.

The full CEO programme is a two-day intensive and interactive workshop, delivered through small group working. Day one covers the policy rationale before introducing the 'CEO Canvas' as the structure for the rest of the day and as a working method to take away and use for curriculum creation or review. The 'CEO Canvas' (Fig. 1) is underpinned by educational concepts and philosophies to provide participants with a structured review process. Through interactive delivery and group work, this also provides opportunities to experience and reflect upon new teaching techniques. Whilst day one concentrates on a broader conceptualisation of enterprise education, day two focuses on entrepreneurship education (QAA 2012) and provides transferable examples of well-used idea and venture generation techniques. During 


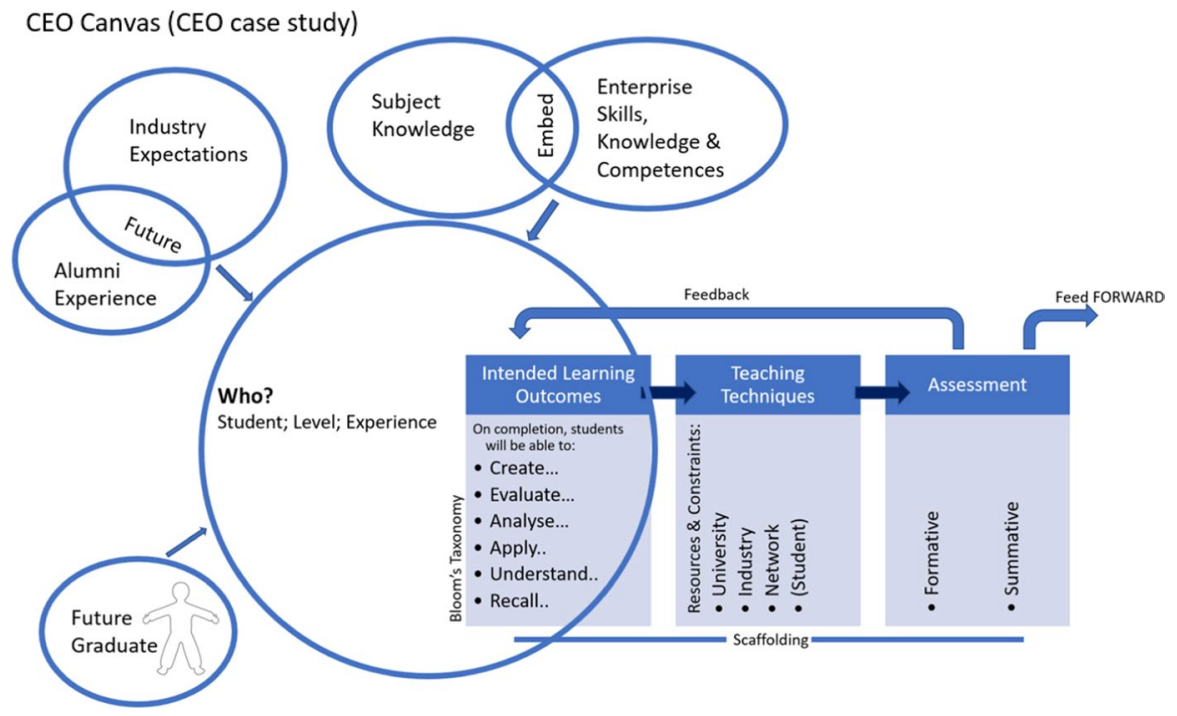

Fig. 1 The CEO programme canvas (Price and Zhang 2018)

day two, participants gain specific participant-led experience of a range of techniques such as customer discovery (Blank and Dorf 2012), business model canvas (Osterwalder and Pigneur 2010), elevator pitching as well as a group-based business simulation. Although not all delegates, especially subject-specific academics, would be expected to teach such specific venture creation techniques, they benefit from experiencing how those topics are delivered, learning to adapt and apply such student-centred teaching techniques.

The CEO programme is highly interactive and demands full engagement of each participant. It is specifically designed to foster an empathetic capacity to 'walk in the shoes' of their students. Delegates are required to work first as a student to experience the tools and techniques and reflect on the learning, and then reflect on its purpose and potential for use within their own teaching. Learning is consolidated by alternating between practice of a teaching technique and reflection on the experience and possible applications in their own contexts. This is structured through six key areas, outlined below:

1 Appreciating context and change: Consider how universities should help graduates prepare for the future challenges brought by the fourth industrial revolution (volatility, uncertainty, complexity and ambiguity);

2 Student focus: Change curriculum design which is centred around learners, learners' competencies and learners' learning outcomes;

3 Constructive alignment: Use Bloom's Taxonomy (1956) and constructive alignment to embed enterprise in the curriculum design;

4 Teaching techniques: Experience approximately 50 teaching techniques, focusing on how to adapt them into their own subject area and teaching;

5 Student engagement: Learn how to better engage and inspire learners; 
6 Support: Build up a network and share classroom experience.

The focus of the CEO programme is threefold. Firstly, it is designed to appreciate the national policy context and seek to change an educators' mindset through an appreciation of the challenges facing graduates. Next, it provides the tools and underpinning principles to support academics from all subject areas to embed enterprise in their curriculum design and delivery so that they can create entrepreneurial graduates who are able to cope with uncertainty, ambiguity and risks in the future. Finally, it provides the educators with the tools to create change in the classroom with their own approaches.

\section{'CEO Canvas': underpinning the programme}

The challenge of developing the educator mindset is formalised through the participant journey offered within the underpinning 'canvas'. The 'CEO Canvas' figure (below) guides the process of curriculum design through a user-/student-centred curriculum development process. This presented as a 'canvas' for the delegates to develop their thinking with, creating a shared tool for groupwork during the programme and designed to drive change as a working tool for post-programme use.

The process unfolds as participants work through the 'CEO Canvas' in small groups. Each cohort experiences a range of facilitated group tasks that seek to address three initial key areas before focusing upon the curriculum. These interactive tasks build a contextualised collective understanding to explore each of these three areas of need:

1 Future graduate: A clear understanding of sector needs can create an overview of the intended outcomes of any programme. Within the CEO programme, the graduate's needs are placed at the core of curriculum development.

2 Sector needs: drawing upon sector/industry changes and alumni advice and guidance can highlight changes that need to be addressed in the delivery of skills development. This intelligence may be drawn from staff, national reporting or sector evidence, as well as programme, module feedback and alumni comments.

3 Enterprise competences: Chinese staff are invited to revisit their traditional starting point for teaching (the knowledge they wish to impart); however, through explicit consideration of entrepreneurial competences (Bacigalupo et al. 2016) a broader articulation of graduate needs is created which includes their entrepreneurial skills and attitudes.

Together these elements create an understanding of the student's future needs, incorporating any industry requirements.

This creates a basis for planning a new curriculum that is rooted within the traditional Chinese approach of knowledge exchange, but now includes an appreciation of preparing students for their futures through the clear development of enterprise competences (McCallum et al. 2018). This is delivered in an interactive workshop style that builds up delegates' understanding whilst demonstrating a range of 
teaching techniques, such as use of post-its, drawing, speed voting, small group discussion, research and presentation. This showcases how entrepreneurial competences are developed, whilst still creating knowledge driven outcomes.

The next process within the 'CEO Canvas' is to actively work through Biggs (2003) constructive alignment. This element incorporates an understanding of student development needs and explores the required scaffolding (Bruner 1960) as well as refocusing much of traditional feedback as feed-forward (Hattie and Timperley 2007). The delegates are then invited to use this process to review or create a specific session, drawing upon the menu of teaching techniques that they have been exposed to during the programme, in order to present their new approach for peer review. Delegates engage with this scaffolded approach and build their own skills and confidence to move from a traditional 'guru'-based teaching style ('sage on the stage') to a more collaborative, student-focused (facilitated) approach to teaching. Delegates are also invited to take this process away and use with colleagues, leading them to create curriculum change.

\section{Programme delivery: within clear principles}

Inspired by QAA $(2012,2018)$ guidance, the CEO programme has been developed to adhere to the principles (Price and Zhang 2018) that now form the accreditation for this model of embedded, engaged and student-focused learning. Designed as generic guidance for enterprise and entrepreneurship education programme development, adherence to these principles assures quality and consistency across all the CEO programmes delivered. These principles are as follows:

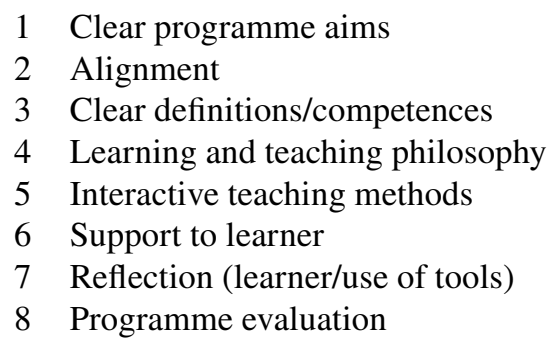

These eight principles are now explored in detail below, outlining how they support pedagogical alignment by recognising and incorporating cultural differences.

\section{Clear programme aims}

Clarity of aim is essential for both curriculum design and delivery. Alignment (see point 2 below) as well as the student experience is impacted by lack of focus. To address this, both the UK and Chinese higher education institutions have created approaches which capture similar information as a module descriptor or template. The traditional teaching in Chinese higher education describes programme aims as the knowledge, skills and students to be mastered. However, the focus within the 
Chinese higher education delivery is then core-text driven knowledge transfer rather than the broader aims of the cognitive, affective and psychomotor domains (Bloom 1956) that are expressed in the aims of UK programmes.

In the case of the CEO programme, at the beginning of the workshop, the following aims are shown to the delegates to role model this approach:

At the end of CEO programme, you will be able to

- Explain the need, context and rationale for enterprise education

- Identify appropriate methods to embed enterprise education into your teaching

- Formulate your own approach embedding enterprise education

During the programme, these intended learning outcomes serve as both an exemplar and demonstration of constructive alignment (Biggs 2003). The above objectives are used as an example of how to set broader learning outcomes using Bloom's (1956) taxonomy. At the end of the two-day workshop, those intended learning outcomes (ILO) are reviewed with the cohort to explore the journey gain and allow delegates to confirm achievement or raise questions as review or for clarification.

\section{Alignment}

In order to achieve the intended learning objectives, educators need to provide students with a safe learning environment which makes good use of available resources and selects relevant teaching techniques that engage students in deep learning and reflection. The CEO programme delivery team work to 'scaffold' (Vygotsky 1978) the whole learning process for cohort and its particular profile of delegates. Participants are invited, towards the end of the Day two, to reflect as to whether the CEO intended learning objectives have been met (as stated in point 1) before then expressing their confidence to demonstrate level of mastery as evidence of the pedagogical alignment (Biggs 2003). The challenge exists for Chinese academics to appreciate how to align practice within their subject discipline. Although institutional practice seeks course plans that identifies skills and attitude as well as knowledge, actual classroom practice sees a focus on knowledge-based content from a prime textbook, without any development of higher-level skills (Bloom 1956) or core competences. This runs counter to the more holistic, student-centred approach in the UK which focuses on intended learning outcomes (ILO) (Biggs, 2003) where objectives are made explicit to students and the programme aims, delivery model and assessment are aligned.

\section{Clear definitions/competences}

Definitions and competences are clearly explained and consistently articulated. Without a guidance such as that offered within the UK QAA guidance (2012 and 2018), many Chinese academics, especially those subject-specific teaching staff, 
report a lack of clarity regarding what to teach and how to teach. During the CEO workshop, the UK and European definitions (QAA 2018; FFE-YE 2012) are shared as references and examples of curriculum design in different subject areas are provided.

\section{Learning and teaching philosophy}

A clear learning and teaching philosophy must be established and then demonstrated consistently throughout delivery. The CEO programme is built upon a philosophy of 'learning by doing' in which the active exploration of each technique is reflected upon (Kolb 1984; Gibbs 1988). Following the maxim 'practice what you preach', the CEO programme team act as key agents curating a structured learning process which facilitates delegates' experiences and supports reflection from both the student and educator's perspectives.

\section{Interactive teaching methods}

To keep students engaged in the learning, teaching staff seek techniques which first and foremost deliver the intended learning outcomes (ILO) but also generate students' interest in order to trigger, what Race (1993) describes, as the core driver, 'wanting to learn'. Students work experientially either individually or in groups to create their own solutions. As shown in the programme feedback and evaluation survey, CEO programme delegates valued the rich variety of the teaching techniques they had experienced throughout the workshop, which offered them a range of alternative approaches to formulate their own methods by combining and adapting.

\section{Support to the learner}

With a clear assessment of the learner (identifying where your students are, where they need to be after learning, what prior knowledge they have, what technologies are accessible), educators will be able to design a programme that addresses the students' needs. A fully supported programme reflects the needs of the learners and provides online or physical resources or demonstrations and provides structured opportunities to reflect and engage with others (network) beyond the duration of the programme. CEO programme creates peer-to-peer support which is designed to nurture reflective practitioners post-programme through shared discussion threads (WeChat) and allows for the active sharing of support materials and resources.

\section{Reflection}

As Dewey (1939) noted, 'we do not learn from experience...we learn from reflection on experience', it is important that facilitated cohort-wide and personal reflection form a key part of the learning and teaching philosophy of the programme. The CEO programme delegates are invited to continue to review their learning after the 
programme and consider their own personal action plan as how to become a reflective practitioner.

\section{Programme Evaluation}

In order to understand whether the learning has been achieved and identify areas for improvement, delegates' views are sought at the end of the programme. Results are shared and reviewed immediately and cumulatively in order to respond to particular needs but also identify longer term trends.

The rubric to support the deeper investigation of these principles is provided in "Appendix".

\section{Case study evaluation: the results}

Since the launch of the CEO programme in July 2017, more than 3000 delegates have participated (either full or part-time). The case study presented here provides analysis of the evaluation of responses collected through online survey which was issued upon completion of the two-day programme. It is important to note that as weak data have been removed, this case study does not include programmes delivered through a host organisation or partner (where the evaluation data was collected by a third party as part of a wider staff development programme. Whilst evaluation and feedback were sought, the required level of detail was not provided by the third party and therefore cannot be included in this case study; however, this obviously forms part of the ongoing management information and evaluation required for the programme management).

To capture reflections and feedback, participants were required to complete an online survey which was conducted ex post via a QR code shared with the participants through their CEO programme cohort discussion thread in order to give their end of programme evaluation within $48 \mathrm{~h}$ of delivery. The data presented here focus upon the core questions that have been consistently asked of all delegates. These focused upon programme satisfaction, expectations of programme delivery, recommendation the programmes to others within a Likert scale. In addition, detailed written responses about 'take-aways' evidenced a delegate's learning experience and their intended commitment to undertaking techniques in the future. Whilst not all participants have provided this more detailed feedback, the majority of delegates regularly continue their reflection and share classroom experiences within the cohort discussion group (WeChat). This allows them to continue to share their progress and reinforce each other's classroom experiences through the examples (photos and short videos) of student work. Other respondents sent their reflections directly to the programme team unprompted; examples of which (text messages) are provided below (Quotation 1-3).

With data from 263 respondents who attended two-day face-to-face full programme as well as 62 respondents whose programme was delivered online during the COVID-19 lockdown (Spring 2020), the data are presented in Table 2. 
Table 2 Analysis of CEO programme participants' feedback CEO

\begin{tabular}{|c|c|c|c|c|c|c|c|}
\hline Year & $\begin{array}{l}\text { Delivery } \\
\text { dates }\end{array}$ & Location & $\begin{array}{l}\text { Par- } \\
\text { ticipant } \\
\text { numbers }\end{array}$ & $\begin{array}{l}\text { Feedback } \\
\text { received } \\
\text { (nos) }\end{array}$ & $\begin{array}{l}\text { Excellent/ } \\
\text { good }\end{array}$ & Fair & $\begin{array}{l}\text { Recom- } \\
\text { mend to } \\
\text { others }\end{array}$ \\
\hline \multirow[t]{3}{*}{2017} & 18/19 July & Dalian & 15 & 15 & 15 & 0 & 15 \\
\hline & 26/27 Nov & Tianjin & 19 & 12 & 12 & 0 & 11 \\
\hline & 01/02 Feb & Ningbo & 18 & 16 & 16 & 0 & 16 \\
\hline \multirow[t]{6}{*}{2018} & 23/24 April & Shijiazhuang & 26 & 22 & 22 & 0 & 21 \\
\hline & 15/16 Sept & Beijing & 18 & 9 & 9 & 0 & 9 \\
\hline & $26 / 27$ Oct & Changsha & 31 & 15 & 15 & 0 & 15 \\
\hline & 02/03 Nov & Guilin & 47 & 12 & 11 & 1 & 11 \\
\hline & 04/05 Dec & Lanzhou & 37 & 19 & 18 & 1 & 18 \\
\hline & 19/20 Dec & Shunde & 50 & 23 & 22 & 1 & 22 \\
\hline \multirow[t]{5}{*}{2019} & 23/24 Mar & Beijing & 11 & 11 & 11 & 0 & 11 \\
\hline & 26/27 May & Changsha & 35 & 35 & 33 & 2 & 35 \\
\hline & $\begin{array}{l}\text { 19/20 } \\
29 / 30 \text { June }\end{array}$ & $\begin{array}{c}\text { Tianjin and } \\
\text { Lanzhou }\end{array}$ & 56 & 48 & 46 & 2 & 48 \\
\hline & $21 / 22$ Nov & Wenzhou & 18 & 11 & 11 & 0 & 11 \\
\hline & 14/15 Dec & Nanning & 20 & 15 & 15 & 0 & 15 \\
\hline \multicolumn{3}{|l|}{ Totals } & 401 & 263 & 256 & 7 & 258 \\
\hline \multicolumn{4}{|c|}{ Totals as percentages of attendees } & $65.59 \%$ & $97.34 \%$ & $2.66 \%$ & $98.10 \%$ \\
\hline \multirow[t]{2}{*}{2020} & Online & Beijing & 83 & 52 & 52 & 0 & 51 \\
\hline & & Nanjing & 20 & 20 & 9 & 1 & 10 \\
\hline \multicolumn{3}{|l|}{ Totals } & 103 & 62 & 61 & 1 & 61 \\
\hline \multicolumn{4}{|c|}{ Totals as percentages } & $60.19 \%$ & $98.39 \%$ & $1.61 \%$ & $98.39 \%$ \\
\hline
\end{tabular}

\section{Analysis}

The findings presented within this case study are based on those who responded to the online survey (approximately 66\% of all the participants) who undertook the full two-day programme. Almost all rated the programme excellent or good (97.34\%) and almost all (98.10\%) would recommend the programme to others.

Of those who indicated the programme was excellent or good, the delegates reported that they liked the structure of the programme, the educational concepts behind the design, the rich variety of teaching techniques demonstrated, the team approach, time for reflection and showcase of examples from different subject areas.

Those who indicated it was fair wanted more techniques they could use in teaching large classes (up to 200 students) with fixed seating and desks and more examples about innovative delivery of traditional subjects. Those who studied online as a result of COVID-19 also identified a desire to attend further training when available in the future. It should be noted that based upon this specific feedback (the large size of Chinese classes and the 2020 global shift in online delivery) future delivery of CEO programmes will seek to address these challenges more explicitly. 
Post-programme impact is demonstrated through the continued peer-to-peer sharing of classroom experiences through WeChat discussion threads. These typically show the techniques in use and include videos/photos of student groups working together or a showcase of their work (presentations or posters). Such learning is also evident within the reflective statements of delegates, of which a typical response presented below:

Quotation 1: 'Teacher Zhang Jing's class was fascinating and memorable. In the class, we learned about the importance of entrepreneurship education in the UK and some of their methods and experience. The problem-based teaching method of group collaboration was adopted throughout the whole process, which unknowingly eliminated the fatigue and slack in training, greatly aroused the students' enthusiasm for learning, and mobilised their enthusiasm for learning. Through these 2 days of learning, I began to think about using innovative and entrepreneurial education thinking to reflect on the professional courses I taught. At present, I am teaching a course of Innovation and Entrepreneurship Practice in Architecture, and the graduation of architecture students is generally based on employment, and there are few entrepreneurial ideas. It is worth exploring how to enable students to develop innovative and entrepreneurial ideas in their minds. In the classroom, students can build up their confidence in entrepreneurship and foster their ability to act'. A delegate from Zhejiang Province who attended the programme in Ningbo, 27-28 August 2017.

With the pedagogical alignment allowing staff to bring their own subject base into course creation, it is clear that student's confidence can be created in context (see Q1 above). In this case, the relevance to the subject discipline (Architecture) creates 'an ability to act' that the original articulation of the original $32 \mathrm{~h}$ model of knowledge transfer would not have developed.

Analysis of this voluntarily, primarily text-based, feedback also evidences that delegates experienced significant mindset change relating to the role of themselves as an educator.

Quotation 2 'After learning these teaching methods, I suddenly realised that our teachers don't have to be so rigid in class. It also allowed me to thoroughly re-examine my teaching methods and strengthened my future steps'. A delegate from Zhejiang Province who attended the programme in Ningbo, 27-28 August 2017

The development of a new educator mindset during the CEO programme has clearly created the critical shift that opens delegates up to changing their teaching methodology (as stated within quotation 2). For this delegate (Q2) this selfdeclared 'sudden realisation' was the key to unlocking a new approach to enterprise education and a new delivery approach. This level of self-examination and reflection supported by an exposure to a wide range of new delivery tools clearly evidences the impact of the approach of the CEO programme. 
Quotation 3 (below) illustrates the shift into a more student-centred mode of delivery, where teacher-student interaction is a critical, and enjoyable, part of the learning.

Quotation 3 'From the international background and domestic experience of innovation and innovation teaching, Zhang Jing talked about the uncertainty that everyone around us can feel. If we can apply what we have learned, teacher-student interaction will be smoother and more enjoyable!'-Cui Zhenqiong, Shunde Polytechnic, 19-20 December 2018.

These quotations evidence a confidence through to creating change in their own practice. Other participants reflections revealed significant changes had taken place in their own practice which had resulted in recognition in their sector. For instance, a polytechnic delegate who attended the programme in December 2017 created his own approach built around the acronym 'IPAD' which won him a provincial teaching award; a Nankai University delegate who attended the programme in November 2017 created significant curriculum change for which she won a university award in May 2019; and a delegate from Shougang Institute of Technology who attended the programme in March 2019 has since been shortlisted for Beijing Municipal Teaching Competition.

\section{Discussion of outcomes}

This paper evidences the recognised participant benefits of a fully aligned and cocreated programme. Through recognition of the differences in the policy focus as well as the profiles of the delegates, a staff development programme that draws from evidenced educational good practice has been created. Working with a deep understanding of the context, culture and needs, it has been possible to develop a programme that meets institutional and national needs, builds staff confidence and supports future delivery. However, from the analysis of the open feedback and delegate experience it is clear that this programme design recognises the following constraints:

Firstly, both the programme design and way of delivery were entirely new to many delegates. They reported that the amount of new information that was explored within 2 days overwhelming and suggested new options for delivery (such as if the programme is broken down into shorter sections (four half-days) to allow participants time to practice and reflect in between).

Secondly, delegates were intentionally from different subject areas. When giving pedagogical examples to illustrate how certain approaches work, the programme team cannot cover all subject areas in detail, rather electing to provide the guidance required for delegates to conceptualise the approach and adapt it to their own field. Unfortunately, as shown in the survey results, it takes time for some delegates to deepen their understanding. Whilst this shows the importance of networking, postprogramme WeChat discussion threads and continued peer-to-peer sharing, it may also explain the unusually high level of interest in repeat attendance that has been experienced. 
Thirdly, delegates in one workshop usually represented mixed institutions (universities or vocational colleges). Upon return, not all of them reported being able to get appropriate support from their leaders or colleagues to take initiatives and changes forward. Environmental constraints and institutional barriers limited practice and those who did make changes were able to do so due to both personal efforts and support from leaders.

Finally, evaluation of the long-term impact will take time and participants' engagement. Whilst many delegates reported that the CEO programme had created a mindset shift, the impact of this would show gradually and would be subject to institutional support. Planned follow-up with the delegates and their employers or students 6 months or 12 months after completion of the programme has been identified as a key future action.

Many of these observations stem from the practical limitations placed by institution in their commissioning of the CEO programme for their staff, or the long-term planning cycles within higher education. Traditional expectations regarding staff development needs (length, timing, availability) together with opportunity (space within the academic year, numbers of staff involved, lead time) created challenges that were accommodated in the design yet shape thinking for the future of the CEO programme development

\section{Conclusions and potential for future research}

Through the CEO programme, a novel and effective approach to staff development has been developed. It delivers for over $95 \%$ of participants through the active showcasing and live demonstration of a clear (and repeatable) process for curriculum change (the 'CEO Canvas') which is rooted in the development of a new educator mindset. Limitations and institutional constraints have been mitigated in the programme design and delivery, whether in person or online, and the overwhelmingly positive delegate response is highly significant. However, it is the self-reported delegate statements that evidence the impact of changing an educator's mindset. Whilst this initial case study serves only to highlight the need for further research to explore the longitudinal impact these educational practices, it also indicates a clear opportunity to focus upon a well-defined cohort now working across mainland China. Exploration of the barriers, implementation challenges as well as the student experience is now needed as CEO delegates now work with these concepts in their own diverse institutional settings across China.

Acknowledgements With grateful thanks for the support of Nick Smith and Lisa McMullan.

\section{Compliance with ethical standards}

Conflict of interest On behalf of all authors, the corresponding author states that there is no conflict of interest. 


\section{Appendix}

The eight principles which underpin the delivery of the CEO programme are presented in detail in the assessment rubric below.

\begin{tabular}{|c|c|c|c|c|c|}
\hline & & $\begin{array}{l}\text { Insufficient dem- } \\
\text { onstration (0) }\end{array}$ & $\begin{array}{l}\text { Minimal demon- } \\
\text { stration (1) }\end{array}$ & $\begin{array}{l}\text { Proficient dem- } \\
\text { onstration (2) }\end{array}$ & $\begin{array}{l}\text { Expertly demon- } \\
\text { strated (3) }\end{array}$ \\
\hline 1 & $\begin{array}{l}\text { Clear Programme } \\
\text { Aims }\end{array}$ & $\begin{array}{l}\text { No clear indica- } \\
\text { tion of planned } \\
\text { approach; no } \\
\text { attempt to } \\
\text { clearly present } \\
\text { what will be } \\
\text { provided as a } \\
\text { 'take-away' } \\
\text { from the pro- } \\
\text { gramme }\end{array}$ & $\begin{array}{l}\text { The agenda of } \\
\text { the programme } \\
\text { was presented } \\
\text { to indicate } \\
\text { the expected } \\
\text { approach. }\end{array}$ & $\begin{array}{l}\text { The agenda } \\
\text { and also clear } \\
\text { programme } \\
\text { aims or learn- } \\
\text { ing outcomes } \\
\text { were high- } \\
\text { lighted (being } \\
\text { presented at } \\
\text { the start of the } \\
\text { programme). }\end{array}$ & $\begin{array}{l}\text { Clear programme } \\
\text { aims (presented } \\
\text { as learning } \\
\text { outcomes) were } \\
\text { presented before, } \\
\text { during and then } \\
\text { also reviewed at } \\
\text { the end of the } \\
\text { programme }\end{array}$ \\
\hline 2 & $\begin{array}{l}\text { Alignment (cer- } \\
\text { tificate/assess- } \\
\text { ment if any) }\end{array}$ & $\begin{array}{l}\text { No clear } \\
\text { approach to } \\
\text { presenting the } \\
\text { programme; } \\
\text { no attempt to } \\
\text { connect content } \\
\text { to what can be } \\
\text { 'taken away'/ } \\
\text { achieved after } \\
\text { the programme }\end{array}$ & $\begin{array}{l}\text { Minimal attempt } \\
\text { to connect the } \\
\text { programme } \\
\text { content (aims) } \\
\text { to the desired } \\
\text { actions/achieve- } \\
\text { ment at the } \\
\text { end of the } \\
\text { programme }\end{array}$ & $\begin{array}{l}\text { There was clarity } \\
\text { about how the } \\
\text { programme } \\
\text { was designed } \\
\text { and what } \\
\text { would be } \\
\text { achieved at the } \\
\text { end (especially } \\
\text { if assessed or } \\
\text { tested) or what } \\
\text { should be done } \\
\text { next (action } \\
\text { plan) }\end{array}$ & $\begin{array}{l}\text { The learning out- } \\
\text { comes presented } \\
\text { at the start of the } \\
\text { programme were } \\
\text { reviewed, and } \\
\text { tested against, } \\
\text { at the end of the } \\
\text { programme (or at } \\
\text { agreed date) }\end{array}$ \\
\hline 3 & $\begin{array}{l}\text { Clear definitions/ } \\
\text { competences }\end{array}$ & $\begin{array}{l}\text { No attempt } \\
\text { to help staff } \\
\text { understand } \\
\text { the core ideas } \\
\text { within enter- } \\
\text { prise education; } \\
\text { no link to } \\
\text { relevant litera- } \\
\text { ture, policy or } \\
\text { practice to help } \\
\text { identify how } \\
\text { to connect this } \\
\text { area with own } \\
\text { subject area or } \\
\text { government } \\
\text { policy }\end{array}$ & $\begin{array}{l}\text { Key words were } \\
\text { presented as } \\
\text { definitions } \\
\text { (but not really } \\
\text { explained } \\
\text { within a subject } \\
\text { content or } \\
\text { connected to } \\
\text { the programme } \\
\text { aims). }\end{array}$ & $\begin{array}{l}\text { Definitions and } \\
\text { terms were } \\
\text { presented/ } \\
\text { agreed at the } \\
\text { start to ensure } \\
\text { a common } \\
\text { language for } \\
\text { the programme } \\
\text { and to explain } \\
\text { the origins of } \\
\text { the approach. } \\
\text { Opportunities } \\
\text { to ask ques- } \\
\text { tions/engage } \\
\text { in discus- } \\
\text { sions with } \\
\text { colleagues/ } \\
\text { work with } \\
\text { the language } \\
\text { were provided } \\
\text { throughout. }\end{array}$ & $\begin{array}{l}\text { The topic areas, } \\
\text { and key words } \\
\text { used throughout } \\
\text { the programme, } \\
\text { were explained/ } \\
\text { defined and the } \\
\text { source/reference } \\
\text { provided. Defini- } \\
\text { tions were up to } \\
\text { date and linked to } \\
\text { the latest policy/ } \\
\text { sector changes. } \\
\text { Opportunities } \\
\text { to discuss the } \\
\text { words/engage } \\
\text { with tasks to } \\
\text { explore meaning } \\
\text { were provided. }\end{array}$ \\
\hline
\end{tabular}




\begin{tabular}{|c|c|c|c|c|c|}
\hline & & $\begin{array}{l}\text { Insufficient dem- } \\
\text { onstration }(0)\end{array}$ & $\begin{array}{l}\text { Minimal demon- } \\
\text { stration (1) }\end{array}$ & $\begin{array}{l}\text { Proficient dem- } \\
\text { onstration (2) }\end{array}$ & $\begin{array}{l}\text { Expertly demon- } \\
\text { strated (3) }\end{array}$ \\
\hline 4 & $\begin{array}{l}\text { Learning and } \\
\text { Teaching Phi- } \\
\text { losophy }\end{array}$ & $\begin{array}{l}\text { No approach } \\
\text { determined } \\
\text { or articulated } \\
\text { to host/client } \\
\text { or delegates. } \\
\text { It was not } \\
\text { clear what } \\
\text { this approach } \\
\text { was, nor was } \\
\text { it consistent to } \\
\text { the message or } \\
\text { throughout the } \\
\text { programme. }\end{array}$ & $\begin{array}{l}\text { The programme } \\
\text { has a specific } \\
\text { approach, but } \\
\text { no reference } \\
\text { was made to } \\
\text { why/how, nor } \\
\text { to how this } \\
\text { approach sup- } \\
\text { ported learning/ } \\
\text { should be used } \\
\text { with students } \\
\text { to create } \\
\text { entrepreneurial } \\
\text { outcomes. }\end{array}$ & $\begin{array}{l}\text { A clear phi- } \\
\text { losophy was } \\
\text { deployed } \\
\text { throughout the } \\
\text { programme } \\
\text { Delegates were } \\
\text { engaged in } \\
\text { a specific } \\
\text { approach(es) } \\
\text { to learning and } \\
\text { the benefits of } \\
\text { this approach } \\
\text { were clear to } \\
\text { the delegates. }\end{array}$ & $\begin{array}{l}\text { A learning } \\
\text { and teaching } \\
\text { philosophy was } \\
\text { established } \\
\text { (pre-programme } \\
\text { through a state- } \\
\text { ment, or during } \\
\text { through example) } \\
\text { and then demon- } \\
\text { strated through- } \\
\text { out consistently. } \\
\text { The approach } \\
\text { taken illustrated } \\
\text { in practice the } \\
\text { philosophy/ } \\
\text { methods in the } \\
\text { programme } \\
\text { design/aims. }\end{array}$ \\
\hline 5 & $\begin{array}{l}\text { Interactive Teach- } \\
\text { ing Methods }\end{array}$ & $\begin{array}{l}\text { Only traditional } \\
\text { methods (such } \\
\text { as lecturing) } \\
\text { are used, to } \\
\text { provide only } \\
\text { knowledge } \\
\text { transfer (no } \\
\text { skill develop- } \\
\text { ment) }\end{array}$ & $\begin{array}{l}\text { Some interac- } \\
\text { tive teaching } \\
\text { techniques were } \\
\text { demonstrated, } \\
\text { but there was } \\
\text { little opportu- } \\
\text { nity to practice } \\
\text { these/consider } \\
\text { how to use } \\
\text { them in own } \\
\text { teaching }\end{array}$ & $\begin{array}{l}\text { Some interac- } \\
\text { tive techniques } \\
\text { were included } \\
\text { in the pro- } \\
\text { gramme, with } \\
\text { opportunities to } \\
\text { discuss whether } \\
\text { they would be } \\
\text { appropriate to } \\
\text { use (benefits } \\
\text { of each) and/or } \\
\text { chances to try } \\
\text { them }\end{array}$ & $\begin{array}{l}\text { A wide range } \\
\text { of appropriate } \\
\text { teaching methods } \\
\text { were used to } \\
\text { share/demon- } \\
\text { strate and show- } \\
\text { case approaches. } \\
\text { The methods } \\
\text { reflected the } \\
\text { teaching philoso- } \\
\text { phy and provided } \\
\text { opportunities to } \\
\text { discuss them and } \\
\text { their benefits and } \\
\text { limitations were } \\
\text { provided, as well } \\
\text { as explore some } \\
\text { in practice/con- } \\
\text { sider adaptations } \\
\text { for use in own } \\
\text { teaching }\end{array}$ \\
\hline
\end{tabular}




\begin{tabular}{|c|c|c|c|c|c|}
\hline & & $\begin{array}{l}\text { Insufficient dem- } \\
\text { onstration }(0)\end{array}$ & $\begin{array}{l}\text { Minimal demon- } \\
\text { stration (1) }\end{array}$ & $\begin{array}{l}\text { Proficient dem- } \\
\text { onstration (2) }\end{array}$ & $\begin{array}{l}\text { Expertly demon- } \\
\text { strated (3) }\end{array}$ \\
\hline 6 & $\begin{array}{l}\text { Support to } \\
\text { learner }\end{array}$ & $\begin{array}{l}\text { No support } \\
\text { materials (as } \\
\text { appropriate- } \\
\text { may include } \\
\text { pre-reading; } \\
\text { slides; access to } \\
\text { web resources; } \\
\text { contact } \\
\text { details-or } \\
\text { creating sup- } \\
\text { port structure } \\
\text { for the group } \\
\text { (at institution } \\
\text { or through } \\
\text { WeChat) }\end{array}$ & $\begin{array}{l}\text { Limited materials } \\
\text { were available } \\
\text { to the delegates } \\
\text { and attempts to } \\
\text { make connec- } \\
\text { tions amongst } \\
\text { the group of } \\
\text { delegates were } \\
\text { attempted. }\end{array}$ & $\begin{array}{l}\text { Working with the } \\
\text { delegates (host/ } \\
\text { client) support } \\
\text { structures } \\
\text { are in place } \\
\text { to provide } \\
\text { momentum to } \\
\text { the learning } \\
\text { provided in the } \\
\text { programme. } \\
\text { This may be } \\
\text { during the pro- } \\
\text { gramme (group } \\
\text { work and creat- } \\
\text { ing networks of } \\
\text { support) or by } \\
\text { the provision of } \\
\text { learning mate- } \\
\text { rials/references } \\
\text { or options of } \\
\text { future engage- } \\
\text { ment. }\end{array}$ & $\begin{array}{l}\text { A fully supported } \\
\text { programme } \\
\text { reflects the needs } \\
\text { of the learners } \\
\text { and will provide } \\
\text { online or physi- } \\
\text { cal resources or } \\
\text { demonstrations } \\
\text { and provide } \\
\text { structured oppor- } \\
\text { tunities to reflect } \\
\text { and engage with } \\
\text { others (network) } \\
\text { beyond the } \\
\text { duration of the } \\
\text { programme. The } \\
\text { course structure } \\
\text { will nurture } \\
\text { support amongst } \\
\text { learners (work } \\
\text { in groups and } \\
\text { networking) }\end{array}$ \\
\hline 7 & $\begin{array}{l}\text { Reflection } \\
\text { (learner/use of } \\
\text { tools) }\end{array}$ & $\begin{array}{l}\text { No direction } \\
\text { to reflect or } \\
\text { opportunities } \\
\text { to reflect were } \\
\text { provided during } \\
\text { the programme }\end{array}$ & $\begin{array}{l}\text { Reflection was } \\
\text { mentioned } \\
\text { as part of the } \\
\text { approach to } \\
\text { using interac- } \\
\text { tive teaching } \\
\text { methods }\end{array}$ & $\begin{array}{l}\text { Reflection tools } \\
\text { were used and } \\
\text { shared during } \\
\text { the programme. } \\
\text { The potential } \\
\text { for learning } \\
\text { through reflec- } \\
\text { tion was clearly } \\
\text { articulated } \\
\text { and options } \\
\text { to engage } \\
\text { learners in this } \\
\text { approach were } \\
\text { provided/dem- } \\
\text { onstrated }\end{array}$ & $\begin{array}{l}\text { Reflection formed } \\
\text { part of the learn- } \\
\text { ing and teaching } \\
\text { philosophy of } \\
\text { the programme } \\
\text { (models and/or } \\
\text { approaches) and } \\
\text { techniques to use } \\
\text { with students/ } \\
\text { clients were dis- } \\
\text { cussed/explored. } \\
\text { Delegates were } \\
\text { invited to con- } \\
\text { tinue to review } \\
\text { their learning } \\
\text { after the pro- } \\
\text { gramme and con- } \\
\text { sider their own } \\
\text { personal action } \\
\text { plan or how to } \\
\text { be a reflective } \\
\text { practitioner }\end{array}$ \\
\hline
\end{tabular}




\begin{tabular}{|c|c|c|c|c|c|}
\hline & & $\begin{array}{l}\text { Insufficient dem- } \\
\text { onstration }(0)\end{array}$ & $\begin{array}{l}\text { Minimal demon- } \\
\text { stration (1) }\end{array}$ & $\begin{array}{l}\text { Proficient dem- } \\
\text { onstration (2) }\end{array}$ & $\begin{array}{l}\text { Expertly demon- } \\
\text { strated (3) }\end{array}$ \\
\hline 8 & $\begin{array}{l}\text { Programme } \\
\text { Evaluation }\end{array}$ & $\begin{array}{l}\text { No opinion } \\
\text { sought from } \\
\text { delegates } \\
\text { regarding con- } \\
\text { tent/programme } \\
\text { delivery or } \\
\text { practical issues } \\
\text { (timing; logis- } \\
\text { tics) }\end{array}$ & $\begin{array}{l}\text { An attempt to } \\
\text { determine } \\
\text { group views/ } \\
\text { comments or } \\
\text { host/client } \\
\text { satisfaction } \\
\text { formed part of } \\
\text { the programme }\end{array}$ & $\begin{array}{l}\text { Structured } \\
\text { evaluation } \\
\text { techniques } \\
\text { (post-its; show } \\
\text { of hands; } \\
\text { comments or } \\
\text { statements or } \\
\text { online survey) } \\
\text { were used to } \\
\text { determine the } \\
\text { success of the } \\
\text { programme } \\
\text { against the } \\
\text { objectives/aims } \\
\text { set }\end{array}$ & $\begin{array}{l}\text { Full evaluation of } \\
\text { the programme } \\
\text { was undertaken } \\
\text { to learn about the } \\
\text { practical/physical } \\
\text { elements and also } \\
\text { to understand the } \\
\text { learning that had } \\
\text { been achieved } \\
\text { Results are shared } \\
\text { and reviewed } \\
\text { with the delivery } \\
\text { team to reflect } \\
\text { upon }\end{array}$ \\
\hline
\end{tabular}

\section{References}

APPG All Party Parliamentary Group Entrepreneurship. (2018). Enterprise Education. London: The Entrepreneurs Network.

Bacigalupo, M., Kampylis, P., Punie, Y., \& Van den Brande, G. (2016). EntreComp: The Entrepreneurship Competence Framework. Publication Office of the European Union; Luxembourg, EUR 27939 http://publications.jrc.ec.europa.eu/repository/bitstream/JRC101581/lfna27939enn.pdf.

Bandura, A. (1977). Self-efficacy: Toward a unifying theory of behavioral change. Psychological Review, 84(2), 191-215.

Bell, R. (2020). Developing entrepreneurial behaviours in the Chinese classroom through value creation pedagogy. Innovations in Education and Teaching International. https://doi.org/10.1080/14703 297.2020.1793800.

Biggs, J. B. (2003). Teaching for quality learning at university (2nd ed.). Buckingham: Open University Press.

Blank, S., \& Dorf, B. (2012). The startup owner's manual: The step-by-step guide for building a great company Pescadero. California: K\&S Ranch Inc.

Bliemel, Martin. (2016). Authentic learning experiences in entrepreneurship: engaging external stakeholders. SSRN Electronic Journal. https://doi.org/10.2139/ssrn.2826331.

Bloom, B. S. (1956). Taxonomy of educational objectives. The classification of educational goals. London: Longman.

Bosma, N., Hill, S., Ionescu-Somers, A., Kelley, D., Levie, J., \& Tarnawa, A. (2020). Global Entrepreneurship Monitor Global Report 2019/2020.

Bruner, J. S. (1960). The Process of Education. ISBN 978-0-674-71001-6.

Department for Trade and Industry (DTI). (2000) White Paper: Excellence and Opportunity-A science and innovation policy for the 21 st Century.

Department for Trade and Industry (DTI). (2003). Innovation Report. Competing in the Global Economy-The Innovation Challenge.

Dewey, J. (1939). In J. Ratner (Ed.), John Dewey's philosophy. New York: The Modern Library.

Elton, L. (1977). In F. Percival, H. I. Ellington, \& P. Race (Eds.), A handbook of educational technology. London: Kogan Page.

Fayolle, A., \& Gailly, B. (2008). From craft to science: Teaching models and learning processes in entrepreneurship education. Journal of European Industrial Training, 32(7), 560-593.

FFE-YE (2012) Impact of Entrepreneurship Education in Denmark-2011 in Vestergard, L, Moberg, K and Jorgensen, C (Eds) Odense The Danish Foundation for Entrepreneurship-Young Enterprise. 
General Office of the Ministry of Education. (2012). Notice of the General Office of the Ministry of Education on printing and distributing the basic requirements of entrepreneurship education and teaching in ordinary undergraduate schools (Trial Implementation). Higher Education Department (2012) No. 4 360A08-07-2012-0023-1.

General Office of the State Council. (2015). Implementation opinions of the general office of the State Council on deepening the reform of innovation and entrepreneurship education in Colleges and Universities State Council Issue (2015) No. 364 May 2015 Science and Education/Higher Education 000014349/2015-00068.

Gibb, A. (1993). Enterprise Culture and education: Understanding enterprise education and its links with small business. Entrepreneurship and Wider Educational Goals, 11(3), 11-34. https://doi. org/10.1177/026624269301100301.

Gibb, A. A. (2002). In pursuit of a new entrepreneurship paradigm for learning: Creative destruction, new values, new ways of doing things and new combinations of knowledge. International Journal of Management Reviews, 4(3), 233.

Gibb, A. A. (2005a). The future of Entrepreneurship Education. Determining the basis for coherent policy and practice. Chapter 2 in Kyro, P and Carrier, C.' The Dynamics of Learning Entrepreneurship in a cross-cultural University Context' University of Tampere Research Centre for Vocational and Professional Education, pp. 44-68

Gibb, A. A. (2005b). Towards the Entrepreneurial University. Entrepreneurship Education as a lever for change. A Policy Paper for the National Council for Graduate Entrepreneurship (NCGE).

Gibb, A. A. (2007a). Entrepreneurship: Unique Solutions for Unique Environments. Is it possible to achieve this with the existing paradigm? International Journal of Entrepreneurship Education, 5, 93-142.

Gibb, A. A. (2007b). IEEP Programme Course. International Entrepreneurship Educators Programme, ncge.

Gibb, A. (2011). Concepts into practice: Meeting the challenge of development of entrepreneurship educators around an innovative paradigm: The case of the International Entrepreneurship Educators' Programme (IEEP). International Journal of Entrepreneurial Behaviour \& Research. https://doi. org/10.1108/13552551111114914.

Gibb, A. A., \& Price, A (Published: 2nd Edition, 2014; first published in 2007) A compendium of pedagogies for teaching entrepreneurship http://ncee.org.uk/wp-content/uploads/2018/01/Compendium -of-Pedagogies.pdf.

Gibbs, G. (1988). Learning by doing: A guide to teaching and learning methods. Further Education Unit. Oxford: Oxford Polytechnic.

Hannon, P. D. (2018). On becoming and being an entrepreneurship educator: a personal reflection. Entrepreneurship and Regional Development, 30(7-8), 698-721. https://doi.org/10.1080/08985 626.2018.1464259.

Hattie, J., \& Timperley, H. (2007). The power of feedback. Review of Educational Research, 77(1), 81-112. https://doi.org/10.3102/003465430298487.

Herrmann, K., Hannon, P., Cox, J., Ternouth, P., \& Crowley, T. (2008). Developing entrepreneurial graduates: Putting entrepreneurship at the centre of higher education. London: NCGE, CIHE, NESTA.

Kill, R., \& O'Rourke, K. (Eds.). (2011). Inspiring enterprise: Transforming enterprise education at Leeds Metropolitan University. Leeds: Leeds Met Press.

Knight, P., \& Yorke, M. (2004). Learning, curriculum and employability in higher education. London: Routledge.

Kolb, D. A. (1984). Experiential learning: Experience as the source of learning and development. Englewood Cliffs, NJ: Prentice-Hall.

Lackeus (2015). Entrepreneurship in Education, What Why When and How, Entrepreneurship 360 Background Paper. Available: http://www.oecd.org/cfe/leed/BGP_Entrepreneurship-in-Education.pdf.

Langston, C. (2018). An interpretative phenomenological analysis of educators' experiences of entrepreneurship education in UK HEIs. University of Aberdeen, unpublished Phd thesis ISNI: 00000004 74320437.

Levie, J. (1999). Enterprising education in higher education in England. A Survey London Business School Department for Education and Employment.

Li, J., Zhang, Y., \& Matlay, H. (2003). Entrepreneurship education in China. Education Training, 45(8/9), 495-505. https://doi.org/10.1108/00400910310508883.

Liu, T., Walley, K., Pugh, G., \& Adkins, P. (2020). Entrepreneurship education in China: Evidence from a preliminary scoping study of enterprising tendency in Chinese university students. 
Journal of Entrepreneurship in Emerging Economies, 12(2), 305-326. https://doi.org/10.1108/ JEEE-01-2019-0006.

Lord Young Review. (2014). Enterprise for all: The relevance of enterprise in education. https://www. gov.uk/government/publications/enterprise-for-all-the-relevance-of-enterprise-in-education.

McCallum, E., Weicht, R., McMullan, L., \& Price, A. (2018). EntreComp into action-Get inspired, make it happen: A user guide to the European Entrepreneurship Competence Framework. In Bacigalupo, M., \& O'Keefe, W. (Eds.), http://publications.jrc.ec.europa.eu/repository/handle/JRC109128.

Neck, H. M., \& Corbett, A. C. (2018). The scholarship of teaching and learning entrepreneurship. Entrepreneurship Education and Pedagogy, 1(1), 8-41. https://doi.org/10.1177/2515127417737286.

Osterwalder, A., \& Pigneur, Y. (2010). Business model generation: A handbook for visionaries, game changers, and challengers. New York: Wiley.

Pepin, M. (2012). Enterprise education: A Deweyan perspective. Education Training, 54(8/9), 801-812. https://doi.org/10.1108/00400911211274891.

Price and Zhang. (2018). Creating Entrepreneurial Outcomes (CEO) programme canvas ETCtoolkit https://www.etctoolkit.org.uk/enterprise-case-studies-library/ceo-staff-development-programmeenterprise-evolution-qaa-1-2-3-4-5-6-7-8-feeuk/.

QAA. (2018). Enterprise and Entrepreneurship Education: Guidance for UK Higher Education Providers. http://www.qaa.ac.uk/docs/qaas/enhancement-and-development/enterprise-and-entrpreneurship -education-2018.pdf?sfvrsn=15f1f981.

Quality Assurance Agency. (2012). Enterprise and entrepreneurship education: guidance for UK higher education providers. (Version 1)

Race, J. (1993). Never mind the teaching-Feel the learning! Quality Assurance in Education, 1(2), 40-43. https://doi.org/10.1108/09684889310044691.

Robinson, S., Dowson, P., \& Price, A. (2008). Ethics, enterprise and employability. In Mossley, D. (Eds.), Discourse: Learning and teaching in philosophical and religious studies, 7(2), 121-156

San Tan, S., \& Ng, C. K. F. (2006). A problem-based learning approach to entrepreneurship education. Education Training, 48(6), 416-428. https://doi.org/10.1108/00400910610692606.

Vygotsky, L. S. (1978). Mind and society: The development of higher psychological processes. Cambridge, MA: Harvard University Press.

Zhang, J. (2018). A gold mine on a wild land. In Conference keynote international entrepreneurship educators conference IEEC Leeds. https://replay.leedsbeckett.ac.uk/Panopto/Pages/Viewe r.aspx?id=809dec1b-4c8a-4e35-94f3-63e67b335b93.

Publisher's Note Springer Nature remains neutral with regard to jurisdictional claims in published maps and institutional affiliations. 